\title{
Strategi Pemasaran Agribisnis Ikan Nila Dalam Di Kecamatan Babirik Kabupaten Hulu Sungai Utara
}

\section{(Marketing Strategy in Tilapia Fish Agribisnis at Babirik District Hulu Sungai Utara Regency)}

\author{
Rum Van Royensyah \\ Program Studi Agribisnis, Sekolah Tinggi Ilmu Pertanian Amuntai \\ Vanroyensyah61@gmail.com
}

\begin{abstract}
ABSTRAK
Penelitian ini bertujuan menganalisis strategi pengembangan agribisnis budidaya ikan nila di Kecamatan Babirik Kabupaten Hulu Sungai Utara. Pengambilan sampel dilakukan dengan multi stage sampling dan pemilihan lokasi kecamatan dilakukan dengan metode purposive sampling, yaitu kecamatan yang paling banyak membudidayakan nila di karamba, yaitu Kecamatan Babirik. Pembudidaya ikan sebagai sampel dipilih secara stratified proporsiones random sampling, sebanyak 8 orang (30\% dari 27 anggota kelompok UPP), dan 57 orang (30\% dari 191 bukan anggota kelompok UPP). Jumlah sampel adalah 65 orang. Sampel kolektor (pedagang pengumpul) dipilih secara snow ball sampling, yaitu 20 orang (30\% dari 65 kolektor). Sampel pengecer dipilih secara accidental sampling di pasar ikan di Kabupaten Hulu Sungai Utara, sebanyak 5 orang. Pemilihan sampel faktor internal UPP Perikanan adalah 8 orang (30\% dari 27 orang), dan Pemilihan Sampel faktor internal non UPP Perikanan adalah 20 orang (30\% dari 191 orang), sedangkan pemilihan sampel faktor eksternal dari institusi terkait adalah 2 orang. Hasil dari matriks evaluasi faktor internal adalah 3.163, sedangkan hasil dari matriks evaluasi faktor eksternal adalah 2.538. Hasil dari matriks eksternal internal ada di sel IV, yaitu pada posisi tumbuh dan bangun, dan strategi agrobisnis nila di karamba di Kecamatan Babirik adalah strategi pengembangan pasar dan produksi.
\end{abstract}

Kata kunci: Strategi, karamba, sampel, internal, eksternal.

\section{ABSTRACT}

This study aims to analyze the strategy of developing tilapia agribusiness in Babirik District, North Hulu Sungai Regency. Sampling was done by multi stage sampling and the selection of sub-district locations was carried out by purposive sampling method, namely the sub-districts which most cultivated tilapia in karamba, namely Babirik District. Fish farmers as samples were selected by stratified proportional random sampling, as many as 8 people (30\% of 27 UPP group members), and 57 people (30\% of 191 were not UPP group members). The number of samples is 65 people. Collector samples (collectors) were selected by snow ball sampling, which was 20 people (30\% of 65 collectors). The sample of retailers was chosen by accidental sampling in the fish market in North Hulu Sungai Regency, as many as 5 people. The selection of Fisheries UPP internal factor samples was 8 people (30\% of 27 people), and the sample selection of non Fisheries UPP internal factors was 20 people (30\% of 191 people), while 2 external factors were selected from the relevant institutions. The results of the internal factor evaluation matrix are 3,163, while the results of the external factor evaluation matrix are 2,538. The results of the internal external matrix are in cell IV, namely in the growth and building position, and the indigo agribusiness strategy in karamba in Babirik District is a market development and production strategy.

Keywords: Strategy, karamba, sample, internal, external.

\section{PENDAHULUAN}

Usaha perikanan di Indonesia masih dalam bentuk usaha perikanan rakyat yang berskala kecil. Usaha perikanan rakyat meliputi kegiatan penangkapan, budidaya

dan pemanfaatan sumberdaya lainnya. Usaha perikanan rakyat memiliki ciri-ciri antara lain : skala usaha kecil, kemapuan 
manajemen rendah, modal lemah, dan produktivitas rendah yang disebabkan oleh karena cara berproduksi yang masih bersifat tradisional.

Perikanan modern pada dasarnya merupakan suatu pembangunan perikanan yang berorientasi agribisnis. Sasaran akhir dari pembangunan perikanan keseluruhan adalah meningkatkan pendapatan sekaligus kesejahteraan bagi para pembudidaya. Untuk mencapai sasaran tersebut, diperlukan langkah-langkah atau strategi pembangunan perikanan yang mengutamakan keterpaduan baik dalam lingkup lintas sektor, antar sektor maupun wilayah. Dengan pendekatan tersebut, diharapkan dapat terwujud suatu pembangunan perikanan yang mantap dan efisien didalam menunjang pembangunan yang berkelanjutan. Pembangunan perikanan semacam itu tidak lain adalah usaha pengentasan kemiskinan dan pengembangan wilayah pesisir dengan pemanfaatan berbagai sumberdaya yang tersedia, melalui peningkatan produktivitas perikanan serta nilai tambah, dengan orientasi agribisnis.

Potensi sumberdaya perikanan dan kelautan yang cukup besar, mengharuskan kita memanfaatkannya secara bertanggung jawab. Pengelolaan yang baik mutlak didasari oleh perencanaan yang baik pula, mewujudkan sistem dan usaha agribisnis maka diperlukan serangkaian kebijakankebijakan pembangunan sebagai berikut. Pertama, kebijakan makro ekonomi yang bersahabat dengan pembangunan sistem dan usaha, kedua kebijakan pengembangan industri yang memberikan prioritas, ketiga kebijakan perdagangan internasional yang netral baik secara sektoral domestik maupun antar negara dalam rangka mewujudkan suatu free trade, keempat pengembangan infrastruktur (jalan, pelabuhan, listrik, telepon, pengairan), kelima pengembangan kelembagaan baik lembaga keuangan, penelitian dan pengembangan pendidikan sumberdaya manusia dan penyuluhan dan pengembangan kelembagaan dan organisasi ekonomi petani, keenam pendayagunaan sumberdaya alam dan lingkungan serta ketujuh, pengembangan pusat-pusat pertumbuhan agribisnis daerah, kedelapan ketahanan pangan.

Usaha budidaya karamba cukup berkembang di Kabupaten Hulu Sungai Utara, khususnya di Kecamatan Babirik terdapat 563 keramba dengan produksi 624.1 ton. Peluang usaha ikan nila dapat memungkinkan dalam berbagai bentuk usaha yang bisa dipilih sesuai dengan minat dan kondisi yang memungkinkan, antara lain ; usaha pembenihan ikan nila, usaha pembesaran ikan nila, dan usaha pemasaran atau distribusi ikan nila.

Kebutuhan benih ikan nila seiring dengan kebutuhan ikan nila konsumsi, dengan demikian peluang usaha terbuka dalam hal pembibitan ikan nila. Metode pembibitan juga relatif lebih mudah, karena Ikan Nila dapat berkembang biak secara alami dengan sangat mudah. Hanya yang diperlukan adalah lahan yang cukup luas. Ikan nila akan berkembang dengan sangat cepat pada areal sawah yang dangkal dan cukup luas dengan suhu air yang cukup hangat. Model pembenihan ikan nila bisa dilakukan dengan sistem mina padi.

Pembinaan pasca panen dan pemasaran merupakan suatu hal yang penting, oleh karena hasil perikanan pada umumnya dicirikan pada sifat : (1). musiman; (2). permintaan untuk konsumsi relatif stabil; (3) mudah rusak; (4) jumlah dan kualitas dapat berubah - ubah keadaan tersebut sering terjadi pada hasil - hasil perikanan sehingga terjadi fluktuasi harga pasar. Sistem pemasaran ikan yang baik harus dapat memberikan keuntungan kepada pelaku pemasaran sekaligus dapat memuaskan konsumen.

Pemasaran merupakan kegiatan yang penting dalam menjarankan usaha pertanian dalam arli luas. karena pemasaran merupakan tindakan ekonomi yang berpengaruh terhadap naik - turunnya pendapatan nelayan/pembudidaya ikan. Disini harga mempunyai peranan sangat penting baik secara poritis maupun ekonomis, karena harga - harga hasil pertanian dan perikanan akan mempengaruhi tingkat pendapatan nelayan dan pembudidaya ikan. 
Permintaan hasil perikanan kebanyakan bersifat inelastis. Dengan demikian apabila jumlah produksi yang ditawarkan rendah/sedikit maka harga akan tinggi dan apabila jumlah produksi yang ditawarkan tinggi/banyak maka harga akan rendah. Dengan adanya kenaikan dan penurunan produksi di setiap saat, maka harga ikan tentu tidak dapat stabil, kecuali apabila ada produsen secara serentak dapat mengatur jumlah produksi yang harus dipasarkan. Menghadapi persaingan pengembangan usaha ikan nila dapat memilih dan mengimplementasikan ke dalam bentuk strategi pengembangan yang dipandang tepat. Keberhasilan usaha dalam memenangkan persaingan sangat tergantung pada strategi pengembangannya yang dipilih dan diaplikasikan dalam pengembangan. Pengembangan strategi ini dipengaruhi beberapa hal, antara lain dari faktor internal dan faktor eksternal perusahaan. Faktor internal perusahaan dapat dikelola dengan baik, sehingga dapat dimanfaatkan sebagai kekuatan untuk menerapkan salah satu strategi pengembangan usaha yang dapat dilakukan, sedangkan faktor eksternal harus dipantau agar mampu mengeksploitasi peluang bisnis yang ada dan dapat mengeliminir ancaman bisnis di lingkungan industri. Oleh karena itu fokus dan perhatian manajemen harus diarahkan pada perumusan strategi yang tepat dengan memanfaatkan faktor-faktor internal dan faktor eksternal, sehingga menjadi kekuatan dalam menghadapi persaingan di pasar.

Penelitian ini bertujuan menganalisis strategi pengembangan agribisnis budidaya ikan nila di Kecamatan Babirik Kabupaten Hulu Sungai Utara.

\section{METODE PENELITIAN}

\section{Tempat dan Waktu Penelitian}

Penelitian ini dilaksanakan di Kecamatan Babirik di Kabupaten Hulu Sungai Utara.

Pengambilan sampel dilakukan secara bertahap (Multi stage sampling) sebagai berikut : (1) Pemilihan lokasi kecamatan menggunakan metode purposive sampling atau secara sengaja, yaitu kecamatan yang terbanyak mengusahakan budidaya ikan nila dalam karamba Yaitu, Kecamatan Babirik Kabupaten Hulu Sungai Utara. (2) Pemilihan petani ikan sebagai contoh, dilakukan dengan dengan cara stratified proporsionesed random sampling, yaitu dengan mengambil petani contoh dari $30 \%$ Kelompok UPP Perikanan dengan jumlah 27 petani contoh sebanyak 8 orang, dan 30\% bukan kelompok UPP Perikanan dengan jumlah 191 petani contoh sebanyak 57 orang. Dengan demikian, jumlah petani contoh seluruhnya sebanyak 65 orang. (3) Pemilihan Contoh faktor internal diambil dari ketua kelompok UPP Pirikanan Kabupaten Hulu Sungai Utara sebanyak 8 orang, dan pemilihan contoh faktor eksternal dari Instansi terkait sebanyak 2 orang.

\section{Analisis Data}

\section{Analisis Matriks IFE dan EFE}

Menurut David dalam Umar (2010) suatu matriks EFE digunakan untuk mengidentifikasi faktor-faktor lingkungan eksternal dan menggolongkannya menjadi peluang dan ancaman bagi perusahaan. Sedangkan matriks IFE digunakan untuk mengidentifikasi faktor-faktor lingkungan internal dan menggolongkannya menjadi kelebihan dan kelemahan perusahaan dengan melakukan pembobotan.

Tahapan-tahapan dalam penyusunan matriks IFE dan EFE adalah :

\section{Identifikasi Faktor Internal dan Eksternal Perusahaan \\ Dalam tahap pengidentifikasian faktor} internal dan eksternal dilakukan dengan mendaftarkan seluruh kekuatan dan kelemahan yang dimiliki oleh perusahaan serta peluang dan ancaman yang dihadapi perusahaan. Data Internal dapat diperoleh dari lingkungan di luar perusahaan, sedangkan data eksternal diperoleh di dalam perusahaan itu sendiri. Faktor bersifat positif (kekuatan) ditulis sebelum faktor yang bersifat negatif (kelemahan), begitu pula dengan tahap identifikasi faktor eksternal perusahaan. 
Pembobotan Faktor eksternal dan internal. Penentuan Ranting (Peringkat) Menurut Rangkuti (2004) penentuan ranting untuk tiap-tiap faktor berdasarkan dengan memberikan skala mulai dari 4 (outstandaring) sampai dengan 1 (poor). Perkalian Bobot dengan Peringkat. Nilai dari pembobotan dikalikan dengan peringkat pada setiap faktor dan semua hasil kali tersebut dijumlahkan secara vertikal untuk memperoleh total pembobotan (David, 2006). Matriks IE, gabungan kedua matriks EFE dan IFE tersebut yang berisikan sembilan macam sel yang memperlihatkan kombinasi total nilai terboboti dari matriks IFE dan EFE. Tujuan penggunaan matriks IE adalah untuk memperoleh strategi bisnis di tingkat perusahaan yang lebih detil. Diagram tersebut dapat mengidentifikasikan sembilan sel strategi perusahaan, tetapi pada prinsipnya kesembilan sel itu dapat dikelompokkan menjadi tiga strategi utama (David, 2006) yaitu :

Tumbuh dan Bina

Divisi yang masuk dalam sel I, II dan IV. Strategi intensif pada divisi ini adalah penetrasi pasar, pengembangan pasar dan pengembangan produk. Strategi intregatifnya adalah strategi intregatif ke depan, ke belakang dan horizontal.

Pertahankan dan Pelihara

Divisi yang masuk dalam sel III, V Dan VII. Strategi yang banyak dilakukan adalah penetrasi pasar dalam pengembangan produk.

Panen dan Divestasi

Divisi yang masuk dalam sel VI, VIII, IX. Merupakan strategi kondisi yang tidak menguntungkan, strategi yang digunakan adalah strategi defensive (divestasi dan lukuidasi).

\section{HASIL DAN PEMBAHASAN}

Strategi pengembangan usaha budidaya ikan nila dalam karamba merupakan suatu proses perubahan yang direncanakan dari suatu keadaan kepada keadaan yang lebih baik dari sebelumnya, untuk meningkatkan pengembangan usaha budidaya ikan nila di Kecamatan Babirik diperlukan adanya suatu strategi yang tepat.
Faktor-faktor yang mempengaruhi strategi pengembangan usaha suatu perusahaan terdiri dari faktor-faktor internal dan eksternal perusahaan.

Strategi adalah sebagai program yang telah di rencanakan oleh sebuah industri atau perusahaan dalam rangka untuk mencapai tujuan. Perumusan strategi usaha budidaya ikan nila diawali dengan menganalisis faktor internal dan faktor eksternal untuk mengidentifikasi faktorfaktor strategi yang menjadi kekuatan dan kelemahan serta peluang dan ancaman dalam perkembangan usaha budidaya ikan nila dalam karamba di Kecamatan Babirik.

\section{Identifikasi Lingkungan Internal}

Lingkungan internal adalah faktor yang berasal dari dalam perusahaan sendiri dan umumnya dapat dikendalikan perusahaan. Analisis lingkungan internal merupakan proses identifikasi dan analisis terhadap kekuatan dan kelemahan dari dalam perusahaan, dengan mengkaji manajemen, pemasaran, operasi dan produksi perusahaan, sumberdaya manusia dan keuangan (David, 2006).

Manajemen, berupa kegiatan perencanaan, pengorganisasian. motivasi, pengelolaan, dan pengendalian. Perencanaan merupakan langkah awal yang akan dilakukan dari semua aktivitas yang berkaitan dengan persiapan dalam mengahadapi masa depan, dalam hal ini juga perlu meramalkan tentang masa depan, perlu menetapkan sasaran, perlu menetapkan suatu strategi, serta juga perlu menetapkan kebijakan keputusan-keputusan apa yang akan diambil dalam memanajemen suatu usaha tersebut.

Pengorganisasian merupakan pengelompokan yang akan memberikan tugas masing-masing kepada setiap orang atau anggotanya untuk mempermudah suatu pelaksanaannya. Dalam kelompok "Maju Bersama" terdapat pembagian tugas yang bagus terdiri dari ketua, penasehat atau pengawas, pembina administrasi teknis, sekretaris, bendahara, wakil sekretaris, wakil bendahara, serta anggota-anggota yang masing-masingya memiliki tugas masingmasing seperti koordinator produksi, 
pemasaran, teknis, perlengkapan, serta koordinator sosial.

Sumberdaya manusia yang melibatkan kelompok "Maju Bersama" mempunyai tingkat pendidikan yang bervariasi mulai dari tingkat lulusan sekolah dasar sampai tingkat lulusan sarjana pun juga ada.

Tingkat pendidikan tidak mengganggu jalannya suatu usaha yang akan dilakukan hal ini bukan menjamin suatu usaha itu sukses, justru tingkat pengalamannya dan keahlian serta keinginanlah yang akan memajukan suatu usaha budidaya ikan nila dalam karamba. Perusahaan akan berjalan dengan lancar apabila didukung juga dengan sumber daya manusia yang baik dan mampu menjalankan sistem tersebut.

Keuangan merupakan salah satu indikator dalam keberjalanan suatu usaha. Keuangan untuk usaha budidaya ikan nila dalam karamba selain modal sendiri, kelompok "Maju Bersma" juga memiliki pinjaman dari bank BRI 6 persen pertahun (7 persen disubsidi pemerintah), satu orang boleh pinjam Rp 50.000.000 (lima puluh juta rupiah) maksimalnya. Misalnya bisa dalam satu kelompok ada 20 orang maka bisa pinjam $20 \times 50.000 .000$ sama dengan 1 milyar (dengan tidak mempertimbangkan jaminan), yang lebih mudahnya pembayaran tidak dilakukan mencicil perbulan melainkan dibayar sekaligus ditambah bunga pertahun.

Manajemen keuangan masih menerapkan sistem manajemen yang sederhana. Pengusaha hanya memperhitungkan aliran keuangan usaha mereka tanpa mencatat atau membukukannya secara rapi. Oleh karena itu, pengusaha tidak dapat mengkalkulasikan secara tepat keungan usaha budidaya ikan nila dalam karamba.

Pemasaran. Menurut David (2006) pemasaran dapat diuraikan sebagai suatu proses menetapkan, mengantisipasi, menciptakan dan memenuhi kebutuhan serta keinginan pelanggan produk dan jasa. Pemilihan pasar sasaran didasarkan adanya peluang potensi pasar yang cukup baik bagi usaha budidaya ikan nila. Dalam hal ini, para pengusaha sendiri yang bertindak dan bertanggunga jawab terhadap pemasaran ikan nila dalam karamba tersebut. Pemasaran ikan nila dalam karamba di Desa Palampitan Hulu dilakukan melalui dua jalur. Pertama, pengusaha sendiri yang memasarkan langsung ikan nila kepasar ikan. kedua, pembeli atau pemesan yang datang kelokasi langsung untuk membeli ikan nila serta bisa memilih ikan nila yang besar-besar. Ikan nila tidak hanya dipasarkan didalam desa saja di luar desa, atau luar Kabupaten seperti Banjarmasin, bahkan sampai keluar Propinsi seperti Samarinda, Sampit, Balikpapan. Untuk pemasaran lokal, umumnya pengusaha memasarkan ikannya di pasar ikan. Pada umumnya pengusaha memasarkan dipasar ikan Banua Lima Amuntai, dipasar ini terkumpul seluruh pengusaha ikan yang ada di Kecamatan Babirik.

Harga merupakan unsur bauran pemasaran yang bersifak fleksibel, artinya dapat diubah dengan cepat penentuan harga dapat dilakukan dengan melihat daya beli konsumen dan jumlah yang cukup dalam menutupi ongkos produksi.

Produksi dan Oprasi. Produksi merupakan suatu rangkaian kegiatan untuk mengubah input menjadi output. Produksi ikan nila sampai ukuran konsumsi memerlukan waktu kurang lebih 3 sampai 4 bulan dengan berat rata-rata per ekor 250 gram sampai dengan 350 gram (4 sampai 5 ekor dalam satu kg). Sebelum memasuki proses panen budidaya ikan nila terlebih dahulu dipersiapkan bahan-bahan yang diperlukan dalam pembuatan karamba yaitu bibit, pakan kayu ulin, paku, baut, dan drum, baik itu drum dari semen ataupun dari plastik. Setelah itu melakukan penebaran bibit, bibit yang ditebarkan sebanyak 500 ekor dalam satu buah karmbanya, setelah itu pemberian pakan, pakan yang diberikan harus memiliki nutrisi atau protein yang baik agar ikan nila cepat berkembang dan tentunya tahan terhadap hama dan penyakit. Pengontrolan dan pembersihan harus sesering mungkin dilakukan agar dapat mengetahui bagaimana kondisi ikan dalam karamba.

\section{Identifikasi Faktor Eksternal}


Faktor politik dan kebijakan pemerintah. Pengembangan sektor usaha kecil dan menengah dirumuskan oleh pemerintah dengan tujuan untuk meningkatkan kesejahteraan masyarakat melalui dukungan permodalan, teknologi dan kemitraan yang mendukung berkembangnya usaha budidaya ikan nila dalam karamba di Kecamatan Babirik. Kebijakan pemerintah untuk usaha budidaya ikan nila dalam karamba di Kecamatan Babirik adalah dengan melakukan bimbingan, dan pelatihan pembudidayaan yang baik sehingga dapat bersaing.

Faktor sosial yang mempengaruhi perusahaan meliputi kenyakinan, nilai-nilai, pendapat dan gaya hidup orang-orang berada dalam lingkungan eksternal. Tingginya tingkat kesadaran masyarakat akan kesehatan, menjadi peluang usaha yang cukup prospektif dalam mengkunsumsi daging ikan nila, selain itu juga mengandung protein yang tinggi baik untuk kesehatan manusia. Ikan nila merupakan ikan yang sangat di gemari oleh masyarakat, ini dibuktikan dengan adanya warung makan siap saji (lamongan), dimana ikan nila sering kosong atau tidak ada, bahkan ikan nila lebih dulu habis di lamongan dibandingkan dengan ayam atau itik.

Budaya merupakan hasil cipta karya manusia usaha budidaya ikan nila sangat diterima di masyarakat, ini terbukti setiap harinya selalu ada pembuatan-pembuatan karamba untuk budidaya ikan nila di daerah Guntung Kecamatan Amuntai Utara yaitu antara 2 sampai 6 buah perharinya.

\section{Faktor teknologi}

Usaha yang dilakukan dalam budidaya ikan nila dalam karamba air yang didapat atau air sungai hanya mengandalkan alami (tidak ada perlakuan khusus), tetapi pakan didapat dari pabrik yang memenuhi nutrisi yang dibutuhkan ikan nila seperti, protein, kabohidrat, lemak, vitamin dan mineral.

Usaha budidaya ikan nila dalam karamba tidak memerlukan teknologi canggih, sampai saat ini, usaha budidaya ikan nila dikerjaan oleh manusia yang memiliki kemampuan khusus dan pengalaman yang ada.

\section{Faktor ekonomi}

Pada umumnya kondisi ekonomi memiliki pengaruh secara langsung terhadap perkembangan suatu pelaku usaha budidaya ikan nila dalam karamba di Kecamatan Babirik. Peluang bagi usaha budidaya ikan nila dalam karamba untuk dapat mengembangkan dan memasarkan hasil usahanya terbuka lebar sehingga dapat meningkatkan pendapatan dan kesejahteraan petani ikan.

\section{Konsumen}

Konsumen sangatlah berperan penting dalam perencanaan strategis dalam suatu usaha sehingga bisa memutuskan suatu strategi yang dipandang tepat sasaran. Pemasok bahan baku untuk pembersaran bibit ikan di Kecamatan Babirik diperoleh dari pabrik yang pakannya memenuhi nutrisi yang dibutuhkan ikan nila, seperti kabohidrat, protein, lemak, vitamin, dan mineral, selain itu juga produk yang dikeluarkan mempunyai sertifikat CPIB (Cara Pembenihan Ikan Yang Baik).

Sehingga benih yang dibeli atau dipasarkan pada petani ikan mempunyai kualitas yang baik, diantaranya cepat besar, tahan terhadap penyakit, tetapi tidak semua UPR (Unit Pembenihan Rakyat) mempunyai sertifikat CPIB (Cara Pembenihan Ikan Yang Baik).

Pesaing yang dihadapi oleh usaha budidaya ikan nila dalam karamba di Kecamatan Babirik terdiri dari budidaya ikan nila itu sendiri, terdapat banyak pesaing usaha budidaya ikan nila dalam karamba di antaranya berada di Desa Palampitan Hulu, Palampitan Hilir, Murung Sari, dan Kelurahan Paliwara.

Ancaman pendatang baru, usaha budidaya ikan nila dalam karamba di Kecamatan Babirik harus memperhatikan adanya ancaman yang masuk bagi pendatang baru, jadi usaha yang selama ini dijalankan harus lebih diperhatikan kualitas produk yang dihasilkan. Hal ini bisa saja terjadi bertambahnya usaha-usaha budidaya ikan nila dalam karamba karena disebabkan adanya dukungan atau bantuan dari 
pemerintah untuk usaha-usaha petani ikan di Kecamatan Babirik khususnya.

Ancaman produk subsitusi pada usaha budidaya ikan nila sewaktu-waktu bisa saja berganti, hal ini dikarenakan adanya ancaman produk pengganti seperti ikan mas, bawal, patin, ataupun lele, tetapi hal ini tidak begitu menghawatirkan karena ikan nila merupakan ikan termasuk katagori yang harga jualnya tnggi diantara ikan yang bisa dibudidayakan.

Kekuatan tawar menawar pemasok, usaha budidaya ikan nila dalam karamba di Kabupten Hulu Sungai Utara memerlukan bahan baku baik itu dari benih ataupun pakan yang unggul dan berkualitas, agar ikan tersebut dapat dengan cepat berkembang biak, dan ikan tersebut juga tahan terhadap hama dan penyakit yang menyerang, ikan-ikan nila yang dihasilkanya mempunyai nutrisi. Dalam usaha budidaya ikan nila di Kecamatan Babirik tidak memiliki kekuatan tawar menawar dalam harga jual bahan baku karena sudah ditetapkan oleh pasar.

Persaingan, usaha-usaha yang membudidayakan ikan nila di Kecamatan Babirik sudah cukup banyak dan hampir setiap sungai tertutupi oleh banyaknya karamba-kamba yang ada, oleh karena itu konsumen bebas memilih ikan yang akan dia beli. Setiap daerah mempunyai karakteristik usaha budidaya yang berbedabeda, dimana sama-sama memiliki keunggulan masing-masing. Dengan demikian banyaknya daerah di Hulu Sungai Utara atau di luar Kabupaten yang mengusahakan budidaya ikan nila, maka petani ikan dituntut agar lebih waspada dan berhati-hati menghadapi persaingan yang semakin ketat.

\section{Matriks IFE}

Faktor yang dianalisis adalah faktor strategi usaha pengembangan budidaya ikan nila dalam karamba di Kabuapten Hulu Sungai Utara, faktor-faktor strategi yang menjadi kekuatan dan kelemahan, selanjutnya dilakukan pemberiaan bobot dan rating. Kekuatan dan kelemahan diperoleh dari perhitungan usaha budidaya ikan nila dalam karamba di Kecamatan Babirik dengan skor tertinggi sebesar 0,520 adalah harga jual relatif terjangkau masyarakat dan lokasi perusahaan usaha strategis mempunyai skor sebesar 0,436, skor tertinggi yang dimiliki variabel tersebut mempunyai pengaruh besar dan diandalkan oleh pengusaha budidaya ikan nila dalam karamba di Kecamatan Babirik.

\section{Matrik EFE}

Analisis faktor eksternal mendefenisikan faktor peluang yang dapat dimanfaatkan oleh perusahaan dan faktor ancaman yang harus dihadapi oleh perusahaan. Analisis faktor eksternal yang dianalisis adalah faktor-faktor strategi eksternal yang terdapat pada usaha budidaya ikan nila dalam karamba yaitu dengan memasukkan nilai hasil identifikasi peluang dan ancaman sebagai faktor strategi eksternal, kemudian memberikan bobot dan rating. Hasil perhitungan dari menjadi peluang dan ancaman usaha budidaya ikan nila dalam karamba di Kecamatan Babirik dengan skor tertinggi sebesar 0,424 dengan dukungan pemerintah dalam pengembangan usaha budidaya ikan nila dalam karamba.

Variabel yang menjadi ancaman utama untuk usaha budidaya ikan nila dalam karamba di peroleh skor sebesar 0,119 persaingan dengan perusahaan sejenis. Hasil analisis matriks EFE untuk peluang dan ancaman diperoleh total rata-rata sebesar 2,538, hal ini menggambarkan bahwa pengembangan usaha budidaya ikan nila dalam karamba di Kecamatan Babirik berada di atas rata-rata $(2,5)$.

\section{Matriks IE}

Kegunaan dari matrik IE adalah untuk mengetahui posisi perusahaan saat ini. Pemetaan posisi perusahaan penting dilakukan dalam pemilihan strategi yang ditetapkan. Hasil analisis matrik EFE diperoleh total nilai tertimbang sebesar 2, 538 dan total nilai dari matrik IFE adalah sebesar 3,163. 


\section{KESIMPULAN}

Analisis lingkungan internal berada pada posisi rata-rata dalam pemanfaatan kekuatan dan kelemahannya. Kekuatan yang paling berpengaruh adalah pada harga jual ikan relatif terjangkau oleh masyarakat atau konsumen, sedangkan yang menjadi kelemahan utama perusahaan adalah tidak adanya pencatatan laporan keuangan. Adapun yang menjadi peluang yaitu, dukungan pemerintah dalam pengembangan usaha budidaya ikan nila dalam karamba di Kabupaten Hulu Sungai Utara yang menjadi ancaman utama yaitu adalah persaingan dengan perusahaan sejenis diantara para pesaing usaha budidaya ikan yang ada. Berdasarkan analisis lingkungan eksternal maka diketahui hasil matriks EFE adalah 2,592 dan matriks IFE adalah 3,073, sehingga diperoleh matriks IE berada pada sel IV yang menggambarkan tumbuh dan bina. Strategi yang digunakan adalah strategi penetrasi pasar, pengembangan pasar, dan pengembangan produk, Strategi pengembangan yang dapat digunakan pada usaha budidaya ikan nila dalam karamba di Kabupaten Hulu Sungai Utara adalah : 1) Strategi penetrasi pasar. Untuk meningkatkan pangsa pasar dapat dilakukan dengan merangsang pelanggan untuk membeli poduk lebih banyak melalui promosi penjualan seperti memberikan tambahan benih atas pembelian yang dilakukan. Selain itu, strategi yang dapat dilakukan adalah memberikan pelayanan yang lebih baik, dengan menjaga ketersediaan benih yang kontinyu, dan menjaga kualitas produk. 2) Strategi Pengembangan pasar yaitu dengan cara meningkatkan informasi pasar guna mengetahui apa yang menjadi selera atau keinginan konsumen saat ini dan dimasa mendatang. 3) Strategi Pengembangan produk yaitu dengan cara menjaga dan meningkatkan kualitas produk dengan memanfaatkan kegiatan penelitian dan pengembangan yang dilakukan oleh perusahaan guna meningkatkan daya saing.

\section{DAFTAR PUSTAKA}

David, F.R. 2006. Manajemen Strategis. Konsep. Edisi Bahasa Indonesia. PT Prehallindo. Jakarta.

Rangkuti, F. 2004. Analisis SWOT Teknik Membedah Kasus Bisnis. PT. Gramedia Pustaka Utama, Jakarta.

Umar, H. 2010. Desain Penelitian Manajemen Strategik. Raja Grafindo Persada : Jakarta. 